\title{
OPEN Author Correction: Temperature, Crystalline Phase and Influence of Substrate Properties in Intense Pulsed Light Sintering of Copper Sulfide Nanoparticle Thin Films
}

\begin{abstract}
Michael Dexter, Zhongwei Gao, Shalu Bansal, Chih-Hung Chang \& Rajiv Malhotra
Correction to: Scientific Reports https://doi.org/10.1038/s41598-018-20621-9, published online 02 February 2018

This Article contains errors in Reference 9 which was incorrectly given as:

Williams, B. A., Smeaton, M. A., Holgate, C. S., Francis, L. F. \& Aydil, E. S. Effect of intense pulsed light annealing on the microstructure of copper zinc tin sulfide nanocrystal coatings. Journal of Vacuum Science es Technology A:
\end{abstract} Vacuum, Surfaces, and Films 34, 1-28, doi:10.1116/1.4961661 (2015).

The correct reference is listed below as ref. 1

\section{Reference}

1. Williams, B. A. et al. Intense Pulsed Light Annealing of Copper Zinc Tin Sulfide Nanocrystal Coatings. J. Vac. Sci. Technol. A. 34, 1-28, https://doi.org/10.1116/1.4961661 (2016).

(c) (i) Open Access This article is licensed under a Creative Commons Attribution 4.0 International License, which permits use, sharing, adaptation, distribution and reproduction in any medium or format, as long as you give appropriate credit to the original author(s) and the source, provide a link to the Creative Commons license, and indicate if changes were made. The images or other third party material in this article are included in the article's Creative Commons license, unless indicated otherwise in a credit line to the material. If material is not included in the article's Creative Commons license and your intended use is not permitted by statutory regulation or exceeds the permitted use, you will need to obtain permission directly from the copyright holder. To view a copy of this license, visit http://creativecommons.org/licenses/by/4.0/.

(C) The Author(s) 2020 